\title{
Supervisi Kepala Sekolah Dalam Meningkatkan Kompetensi Profesional Guru di SMA Kartika XIX-1 dan SMA PGII 2 Kota Bandung
}

\author{
Noviyanti $^{1}$, Suharyanto ${ }^{2}$, Rajaminsah ${ }^{3}$ \\ 1,2,3 Sekolah Pascasarjana, Universitas Islam Nusantara Bandung \\ E-mail: nhovy19@gmail.com
}

\begin{tabular}{l}
\hline Article Info \\
\hline Article History \\
Received: 2021-08-20 \\
Revised: 2021-09-10 \\
Published: 2021-10-08 \\
\\
Keywords: \\
Supervision; \\
Principal; \\
Professional Competence; \\
Teacher.
\end{tabular}

\begin{abstract}
This study discusses matters relating to the planning, implementation and evaluation of academic supervision with programs, facilities/infrastructure, curriculum and human resources as instrumental elements of input and supervision/assessment as environmental input. The specific purpose of this research is to know the planning, implementation and evaluation of the principal's academic supervision in improving the professional competence of teachers. The theological foundation in this research is Q.S. Al-Maidah: 2. This study uses a qualitative approach with a descriptive method. Data collection was obtained by using the methods of observation, interviews and documentation studies. The findings of this study indicate that (1) the planning of the principal's academic supervision by making a supervision program and a schedule of supervision and coaching (2) The implementation of the principal's academic supervision is carried out through class visits and academic supervision is carried out regularly every year (3) evaluation of the results of academic supervision, The principal holds a meeting with the teacher concerned to discuss the results of the supervision and discuss the follow-up plan with the supervised teacher. The conclusion of this study is that with the academic supervision of the principal, the professional competence of subject teachers can be seen from the increased ability to master the material and knowledge that can be applied in the classroom so that fun and creative learning can be created so as to achieve quality graduates.
\end{abstract}

\begin{tabular}{l}
\hline Artikel Info \\
\hline Sejarah Artikel \\
Diterima: $2021-08-20$ \\
Direvisi: $2021-09-10$ \\
Dipublikasi: $2021-10-08$
\end{tabular}

Kata kunci:

Supervisi;

Kepala Sekolah;

Kompetensi Profesional; Guru.

\begin{abstract}
Abstrak
Penelitian ini membahas hal yang berkaitan dengan perencanaan, pelaksanaan dan evaluasi supervisi akademik dengan program, sarana/prasarana, kurikulum dan SDM sebagai unsur instrumental input dan pengawasan/penilaian sebagai environmental input. Tujuan khusus dari penelitian ini yaitu mengetahi perencanaan, pelaksanaan dan evaluasi supervisi akademik kepala sekolah dalam meningkatkan kompetensi profesional guru. Landasan teologis dalam penelitian ini adalah Q.S. Al-Maidah : 2. Penelitian ini menggunakan pendekatan kualitatif dengan metode deskrpitif. Pengumpulan data diperoleh dengan menggunakan metode observasi, wawancara dan studi dokumentasi. Temuan penelitian ini menunjukkan bahwa (1) Perencanaan supervisi akademik kepala sekolah dengan pembuatan program supervisi dan jadwal supervisi serta pembinaan (2) Pelaksanaan supervisi akademik kepala sekolah dilaksanakan melalui kunjungan kelas dan supervisi akademik dilaksanakan secara rutin setiap tahun (3) evaluasi hasil supervisi akademik, kepala sekolah mengadakan pertemuan dengan guru yang bersangkutan untuk membicarakan hasil dari supervisi dan membicarakan rencana tindak lanjut kepada guru yang disupervisi. Simpulan dari penelitian ini bahwa dengan adanya supervisi akademik kepala sekolah, kompetensi profesional guru mata pelajaran dapat terlihat dari meningkatnya kemampuan penguasaan materi dan ilmu pengetahuan yang dapat di apikasikan didalam kelas sehingga dapat terciptanya pembelajaran yang menyenangkan dan kreatif sehingga tercapainya kualitas lulusan yang bermutu.
\end{abstract}

\section{PENDAHULUAN}

Pembangunan bidang pendidikan yang dilaksanakan pada saat ini merupakan implementasi yang telah diamanatkan oleh Undang Undang Dasar 1945 maupun Undang-Undang Nomor 20 Tahun 2003 tentang Sistem Pendidikan Nasional. Berdasarkan Undang-
Undang Nomor 20 Pasal 3 Tahun 2003 menyatakan bahwa Sistem Pendidikan Nasional berfungsi mengembangkan kemampuan dan membentuk watak serta peradaban bangsa yang bermartabat dalam rangka mencerdaskan kehidupan bangsa, bertujuan untuk berkembangnya potensi peserta didik agar menjadi 
manusia yang beriman dan bertaqwa kepada Tuhan Yang Maha Esa, berakhlak mulia, sehat, berilmu, cakap, kreatif, mandiri dan menjadi warga negara demokratis serta bertanggung jawab. Penyataan tersebut menguatkan lembaga/ sekolah harus mampu menghasilkan manusia yang berkualitas serta di dukung sumber daya manusia yang berkualitas dengan di sertai proses pembangunan pendidikan yang dilaksanakan mulai dari perencanaan program sampai dengan proses pengendalian atau pengawasan terhadap pencapaian tujuan program.

Salah satu sumber daya manusia dalam penyelenggaraan pendidikan adalah kepala sekolah. Kepala sekolah mempunyai peranan penting dalam mempengaruhi sistem dalam sekolah, kepala sekolah adalah orang yang berada di depan dalam mengkoordinasikan upaya meningkatkan pembelajaran yang bermutu. Sebagai pemimpin di sekolah, kepala sekolah memiliki peran yang cukup besar dalam membina kemampuan guru dalam proses pembelajaran. Untuk membuat guru menjadi profesional tidak hanya meningkatkan kompetensi melalui pemberian penataran, pela-tihan maupun kesempatan untuk belajar lagi, namun kepala sekolah perlu memperhatikan guru dari segi lain seperti peningkatan disiplin, pemberian motivasi, pemberian bimbingan melalui supervisi.

Pengertian supervisi yang berdasarkan wikipedia, yaitu supervisi secara etimologi berasal dari kata "super" dan "visi" yang mengandung arti melihat dan meninjau dari atas atau menilik dan menilai dari atas yang dilakukan oleh pihak atasan terhadap aktivitas, kreativitas, dan kinerja bawahan, dalam hal ini pihak atasan adalah kepala sekolah terhadap bawahan adalah Guru. Salah satu kompetensi yang harus dimiliki oleh kepala sekolah adalah kompetensi supervisi. kompetensi supervisi sesuai permendiknas nomor 13 tahun 2007 mencakup perencanaan program supervisi akademik dalam rangka peningkatan profesional guru, melaksanakan supervisi akademik terhadap guru dengan menggunakan pendekatan dan tehnik supervisi yang tepat dan menindaklanjuti hasil supervisi akademik terhadap guru dalam rangka peningkatan profesional guru. Berdasarkan penelitian pendahuluan pada beberapa SMA di Kota Bandung, menunjukkan bahwa supervisi akademik kepala sekolah belum berjalan secara optimal hal ini dikarenakan belum optimalnya dalam perencanaan, pelaksanaan, penilaian dalam supervisi sehingga berdampak negatif terhadap kompetensi profesional Guru. Menurut Hermino (2014: 169) menyatakan bahwa:

"Profesional guru mempunyai peranan penting dalam peningkatan mutu pendidikan karena profesional guru memberikan jaminan perlindungan kepada kesejahteraan masyarakat umum, merupakan suatu cara untuk memperbaiki citra profesi pendidikan yang selama ini dianggap oleh sebagian masyarakat rendah, memberikan kemungkinan perbaikan dan pengembangan diri yang memberikan pelayanan sebaik mungkin dan memaksimalkan kompetensinya. Sehingga profesional guru dapat sangat besar peranannya dalam upaya meningkatkan mutu pendidikan karena guru adalah merupakan komponen penting dalam proses pembelajaran."

Dalam proses pendidikan di sekolah, guru memegang tugas ganda yaitu sebagai pengajar dan pendidik. Sebagai pengajar guru bertugas menuangkan sejumlah bahan pelajaran ke dalam otak anak didik, sedangkan sebagai pendidik guru bertugas membimbing dan membina anak didik agar menjadi manusia susila yang cakap, aktif, kreatif, dan mandiri. Oleh sebab itu, tugas yang berat dari seorang guru ini pada dasarnya hanya dapat dilaksanakan oleh guru yang memiliki kompetensi profesional yang tinggi. Namun pada kenyataannya banyak diantara guru disinyalir kurang memenuhi kualifikasi akademik dan kinerja yang kurang memadai.

Guru memiliki pengaruh luas dalam dunia pendidikan dikarenakan guru merupakan salah satu komponen yang memegang peranan sangat penting antara lain menyiapkan materi, menyampaikan materi, serta mengatur kegiatan belajar mengajar dan proses pembelajaran. Di sekolah guru adalah pelaksana administrasi pendidikan yaitu bertanggung jawab agar pendidikan dapat berlangsung dengan baik. Kompetensi profesional merupakan salah satu kompetensi yang harus dimiliki oleh setiap guru dalam jenjang pendidikan apapun. Kompetensikompetensi lainnya adalah kompetensi pedagogik, kompetensi kepribadian dan kompetensi sosial. Sebagaimana diterangkan dalam Undang-Undang Republik Indonesia nomor 14 tahun 2005 Bab IV pasal 10 ayat 1 tentang guru dan dosen yaitu: "kompetensi guru meliputi kompetensi pedagogik, kompetensi kepribadian, kompetensi sosial dan kompetensi profesional yang diperoleh melalui pendidikan profesi, keempat kompetensi ini saling berkaitan". 
Berdasarkan observasi di lapangan, masih banyak guru yang belum terbentuk profesionalnya atau hanya ditunjang oleh sebagian saja dari dari keempat kompetensi tersebut serta masih banyak guru yang belum memperhatikan tentang pentingnya kompetensi yang harus dimiliki oleh seorang guru. Rendahnya kompetensi sebagian guru yang belum memperhatikan disebabkan belum maksimalnya kepala sekolah membina dan mengarahkan untuk melakukan supervisi terhadap guru yang belum maupun yang sudah memahami tentang tentang kompetensi guru. Berdasarkan latar belakang masalah diatas, dipandang perlu adanya penelitian lebih lanjut agar dapat ditemukan data yang akurat dan dapat ditentukan alternatif pemecahannya tentang pelaksanaan supervisi akademik oleh kepala sekolah dalam meningkatkan kompetensi profesional guru. Data penelitian ini dibuat untuk memberikan gambaran dan wawasan yang komprehensif tentang supervisi akademik yang dilakukan oleh kepala sekolah pada proses pembelajaran dalam meningkatkan kompetensi profesional guru di sekolah, baik di sekolah negeri maupun swasta.

a. Konsep Supervisi dalam Islam

Supervisi pada dasarnya adalah proses pemberian bantuan kepada orang lain, artinya seseorang yang memiliki kompetensi lebih (supervisor) memberikan pertolongan kepada guru kaitannya dengan proses pembelajaran untuk meningkatkan kualitas hasil belajar peserta didik, dengan adanya bantuan ini seorang guru dapat melaksanakan tugasnya dengan baik. Seorang supervisor dalam hal ini kepala sekolah harus mentikberatkan perhatiannya pada segala langkah perbaikan dan peningkatan kualitas pembelajaran yang telah di ptuskan bersama. Ajaran Islam sangat menganjurkan untuk saling tolong menolong, sebagaimana firman Allah dalam Al-Qur'an. Artinya: "Dan tolong-menolonglah kamu dalam (mengerjakan) kebaikan dan taqwa, dan jangan tolong menolong dalam berbuat dosa permusuhan. Bertaqwalah kepada Allah, sungguh, Allah sangat berat siksaNya."(Q.S. Almâidah:2)Kaitannya dengan supervisi pendidikan dan pengajaran, ayat di atas dapat dipahami bahwa pemberian bantuan oleh supervisor kepada guru dalam hal meningkatkan kualitas pembelajaran tidak diragukan lagi adalah suatu pertolongan dan bentuk kerja sama dalam kebaikan, akan tetapi dalam proses pemberian bantuan profesional itu harus dilaksanakan dengan dasar kebaikan dan ketaqwaan.

b. Supervisi sebagai Bentuk Pengawasan

Sekolah sebagai organisasi memiliki sistem manajemen tersendiri yang dilakukan oleh kepala sekolah beserta stafnya. Sebagai salah satu fungsi manajemen adalah pengawasan (controlling) yang merupakan unsur penting dalam sebuah organisasi, controlling berupaya agar rencana yang sudah ditetapkan dapat tercapai sebagaimana mestinya. Pengawasan sebagai upaya agar setiap kegiatan berjalan sesuai dengan yang diharapkan dan yang lebih penting tidak terjadi penyimpangan terhadap perencanaan yang telah ditetapkan. Menurut Widjaja (1993: 343) "pengawasan adalah proses memonitor aktivitas untuk memastikan aktivitas-aktivitas tersebut diselesaikan sesuai dengan yang direncanakan dan memperbaiki setiap deviasi yang signifikan." Menurut Govindarajan (1998: 28) : "Controlling atau pengawasan merupakan salah satu aspek penting dalam dinamika sebuah organisasi, baik organisasi dalam bentuk perusahaan, pendidikan msaupun yang lainnya. Selain sebagai bagian integral dari proses atau tahapan kinerja organsasi yang dimulai dari planning, organizing, actuating sampai controlling, dalam beberapa studi manajemen juga menunjukkan bahwa upaya pengawasan yang tereduksi dalam sebuah sistem kerja organisasi berpengaruh sangat signifikan terhadap peningkatan kinerja organisasi secara keseluruhan." Berdasarkan kedua pengertian tersebut, dapat disimpulkan bahwa pengawasan (controlling) adalah suatu kegiatan atau aktivitas yang dilaksanakan dengan maksud agar tujuan yang sudah ditetapkan sesuai rencana atau tidak, jika aktivitas tersebut tidak sesuai dengan perencanaan maka perlu adanya revisi.

c. Pengertian Supervisi Akademik

Keterampilan utama dari seorang pengawas (kepala sekolah) adalah melakukan penilaian dan pembinaan kepada guru untuk secara terus menerus meningkatkan kualitas proses pembelajaran yang dilaksanakan di kelas agar berdampak pada kualitas hasil belajar siswa. Untuk dapat mencapai kompetensi tersebut pengawas diharapkan dapat melakukan pengawasan akademik yang didasarkan pada metode dan teknik supervisi yang tepat sesuai dengan kebutuhan guru. 
Sergiovani dan Starrat dalam Mulyasa (2006: 111) menyatakan bahwa "Supervision is a process designed to help teacher ad supervisor learn more about their practice; to better able to use their knowledge and skills to better serve parents and schools; and to make the schools a more effective learning community". Kutipan tersebut menunjukkan bahwa supervisi merupakan suatu proses yang dirancang secara khusus untuk membantu para guru dan supervisor dalam mempelajari tugas seharihari disekolah; agar dapat menggunakan pengetahuan dan kemampuannya untuk memberikan layanan yang lebih baik kepada orang tua peserta didik dan sekolah, serta berupaya menjadikan sekolah sebagai masyarakat belajar yang lebih efektif.

Menurut Sudiyono dan Prasojo (2011: 94) menyatakan bahwa "supervisi akademik adalah serangkaian kegiatan untuk membantu guru mengembangkan kemampuannya mengelola proses pembelajaran demi pencapaian tujuan pembelajaran." Menurut Mc Nerney (1951: 1) dalam Suharti (2011: 5) "supervisi adalah prosedur memberi arah serta mengadakan penilaian secara kritis terhadap proses pengajaran." Menurut Kimbal Willes (1955:8-11) dalam Suharti (2011: 6) "supervisi adalah bantuan yang diberikan untuk memperbaiki situasi belajar mengajar yang lebih baik. Hal yang menjadi perhatian utama bagi supervisi di sekolah-sekolah adalah masalah mutu pengajaran dan mutu perbaikannya." Berdasarkan pengertian tersebut maka dapat disimpulkan bahwa supervisi adalah usaha memberikan layanan kepada guru-guru, baik secara individual maupun secara kelompok dalam usaha memperbaiki pengajaran dan merupakan fungsi yang ditujukan pada penjaminan mutu proses belajar-mengajar yang dilakukan oleh guru serta yang dari supervisi ini adalah mengkaji, menilai, memperbaiki, meningkatkan, dan mengembangkan mutu kegiatan belajar-mengajar yang dilakukan bersama dengan guru (perorangan atau kelompok) melalui pendekatan bimbingan dan konsultasi dalam nuansa dialog profesional. Supervisi akademik merupakan upaya membantu guruguru mengembangkan kemampuannya mencapai tujuan pembelajaran. Dengan demikian, berarti, esensi supervisi akademik itu sama sekali bukan menilai unjuk kerja guru dalam mengelola proses pembelajaran, melainkan membantu guru mengembangkan kemampuan profesionalismenya.

d. Kompetensi Kepala Sekolah

Kepala sekolah adalah jabatan strategis yang tidak mudah dan tidak semua orang akan mampu mengembannya dan menjalankan semua tugas jabatan kepala sekolah. Kunci dalam menentukan kemajuan dan kesuksesan sebuah sekolah sebagai lembaga pendidikan adalah keterampilan dan kecekatan dari kepala sekolahnya. Kemampuan dan kapasitas intelektual, emosional, spiritual dan sosial harus dimiliki oleh guru jika ingin mengemban tugas tambahan sebagai kepala sekolah. Kemampuankemampuan tersebut akan sangat mempengaruhi efektifitas kepemimpinannya. Sementara, kedalaman ilmu, keluasan pikiran, kewibawaan dan relasi komunikasinya akan membawa membawa perubahan signifikan dalam manajemen sekolah yang menjadi tanggung jawabnya. Oleh karena itu, kepala sekolah harus terus menerus meningkatkan kompetensinya dari hari ke hari dan dari waktu ke waktu agar tetap dapat mengimbangi perubahan-perubahan yang ada, sehingga kepala sekolah akan menjadi motor penggerak bagi program-program kerja yang strategis dalam rangka meningkatkan dan memajukan kualitas pendidikan di sekolah yang dipimpinnya. Berdasarkan Permendikbud Nomor 13 tahun 2007 menyatakan lima kompetensi yang harus di miliki oleh seorang kepala sekolah adalah sebagai berikut: "(1) Kompetensi Kepribadian: kepribadian tidak hanya pesona, sikap positif terhadap hidup, wajah yang tersenyum, tetapi kepribadian juga suatu konsep dinamis yang menggambarkan pertumbuhan dan pengembangan dari sistem psikologis keseluruhan dari seseorang. Kepribadian yang sopan santun dan penyayang serta mengayomi sangat diperlukan bagi kepala sekolah; (2) Kompetensi Manajerial: Kompetensi manajerial kepala sekolah dapat dilihat dari kemampuanya dalam menyusun perencanaan sekolah untuk berbagai tingkat perencanaan, pengembangan organisasi sekolah sesuai dengan kebutuhan, kepemimpinan sekolah dalam rangka pendayagunaan sumber daya sekolah secara optimal, mengelola perubahan dan pengembangan sekolah menuju organisasi pembelajaran yang efektif, menciptakan budaya dan iklim sekolah pembelajaran yang efektif, menciptakan 
budaya dan iklim sekolah yang kondusif dan inovatif bagi pembelajaran peserta didik; (3) Kompetensi Kewirausahaan: Kompetensi kewirausahaan menjadi sangat penting buat kepala sekolah karena kompetensi ini berkaitan dengan tantangan persaingan antar sekolah dimasa mendatang; (4) Kompetensi Supervisi: Kepala sekolah sebagai penanggung jawab utama dalam semua kegiatan sekolah dituntut agar dapat menyelenggarakan pendidikan secara baik dan produktif. Persoalannya adalah bahwa dalam penyelen-ggaraan pendidikan tersebut kepala sekolah tidak mungkin melaksanakan seluruh kegiatan sendiri, oleh karena itu ada pendelegasian kepada guru maupun staf, untuk memastikan bahwa pendelegasian tugas itu dilaksanakan secara tepat waktu dengan cara yang tepat atau tidak maka diperlukanlah supervisi yaitu menyelia pekerjaan orang lain.;

Kompetensi Sosial: Kompetensi sosial kepala sekolah adalah kemampuan untuk berkomunikasi dan berinteraksi secara efektif dan efisien, baik dengan peserta didik, guru, orang tua/wali, dan masyarakat sekitar, sehingga seorang yang memiliki kompetensi sosial akan nampak menarik, empati, kolaboratif, suka menolong, menjadi panutan, komunikatif, dan kooperatif".

e. Kompetensi Profesional Guru

Dalam Standar Nasional Pendidikan, penjelasan Pasal 28 ayat (3) butir c dikemukakan bahwa: "kompetensi professional adalah kemampuan penguasaan materi pembelajaran secara luas dan mendalam yang memungkinkan membimbing peserta didik memenuhi standar kompetensi yang ditetapkan dalam Standar Nasional Pendidikan". Menurut UU No. 14 Tahun 2005 tentang Guru dan Dosen menyatakan bahwa: "kompetensi profesional ialah kemampuan atau keahlian yang harus dimiliki oleh guru mencakup guru mampu menguasai materi, struktur, konsep dan pola pikir keilmuan yang mendukung mata pelajaran yang diampu, guru mampu menguasai standar kompetensi dan kompetensi dasar, guru mampu mengembangkan materi pelajaran secara kreatif, guru mampu mengembangkan keprofesionalan secara berkelanjutan dan guru mampu memanfaatkan teknologi informasi dan komunikasi (TIK) untuk berkomunikasi dan mengembangkan diri". Berdasarkan kedua pernyataan tersebut dapat disimpulkan bahwa kompetensi profesional artinya guru harus memiliki pengetahuan yang berkenaan dengan konsep teoretis, mampu memilih model, strategi dan metode yang tepat serta mampu menerapkannya dalam kegiatan pembelajaran, serta seorang guru harus memiliki pengetahuan yang luas tentang kurikulum dan landasan kependidikan dan dapat menyelesaikan ugastugas keguruan dengan baik.

\section{METODE PENELITIAN}

Metode penelitian ini yaitu menggunakan pendekatan kualititatif dengan penelitian deskriptif. Dapat dikatakan bahwa penelitian deskriptif merupakan penelitian yang berusaha mendeskripsikan suatu gejala, peristiwa yang terjadi pada saat sekarang atau masalah aktual. Teknik pengumpulan data dalam penelitian ini menggunakan teknik pengumpulan data wawancara, observasi terlibat dan dokumentasi. Teknik pengolahan data yang digunakan dalam penelitian ini adalah reduksi data, display data dan menarik kesimpulan. Tempat penelitian yang digunakan pada penelitian ini yaitu SMA Kartika XIX-1 dan SMA PGII 2 kota Bandung yang beralamat di Jl. Taman Pramuka No.163, Cihapit, Kec. Bandung Wetan, Kota Bandung, Jawa Barat 40114. Dan Jalan Pahlawan Belakang No.17, RT.07/RW.06, Cihaur Geulis, Kec. Cibeunying Kaler, Kota Bandung, Jawa Barat 40122.

\section{HASIL DAN PEMBAHASAN \\ A. Hasil Penelitian}

1) Kegiatan Kepala sekolah dalam merencanakan Supervisi Akademik untuk meningkatkan kompetensi profesional guru

\section{a. SMA Kartika XIX-I}

Berdasarkan hasil observasi, wawancara dan studi dokumentasi, Kegiatan kepala sekolah dalam merencanakan program supervisi menurut Kepala SMA Kartika XIX-1 sebelum program supervisi disusun, kepala sekolah mempunyai agenda rutin setiap awal tahun pelajaran yaitu mengadakan In House Training mengenai pembinaan kurikulum, pembelajaran dan penilaian kepada guru-guru termasuk guru mata pelajaran khususnya. Setelah agenda ini dilaksanakan barulah program supervisi disusun dan pada dasarnya pelaksanaan disusun dalam program, setiap tahun. Dalam satu tahun pelajaran minimal dua kali supervisi 
dengan jadwal yang disusun dan disesuaikan dengan kepentingan atau tujuan supervisi dan kalender pendidikan.

\section{b. SMA PGII 2}

Berdasarkan hasil observasi, wawancara dan studi dokumentasi dengan kepala SMA PGII 2 bahwa sebelum program supervisi disusun, kepala sekolah mempunyai agenda rutin setiap awal tahun pelajaran yaitu mengadakan In House Training mengenai pembinaan kurikulum, pembelajaran dan penilaian kepada guru-guru termasuk guru mata pelajaran khususnya. Perencaaan supervisi akademik disekolah dilakukan melalui suatu rancangan program supervisi akademik setiap tahun pelajaran yang dilaksanakan hanya satu kali dalam satu tahun pelajaran yaitu di setiap bulan oktober. Pada awal tahun pelajaran kepala sekolah menyelenggarakan rapat dewan guru, adapun konten dari rapat tersebut anatara lain menginfromasikan tugas pokok dan fungsi guru, pembagian tugas mengajar dan tugas- tugas lainnya bagi para guru. Perencanaan supervisi akademik disusun dalam program

2) Kegiatan Kepala sekolah dalam melaksanakan Supervisi akademik dalam meningkatkan kompetensi profesional guru.

\section{a. SMA Kartika XIX-I}

Berdasarkan hasil observasi, wawancara dan studi dokumentasi dengan Kepala SMA Kartika XIX-1 pada hari Senin, tanggal 16 Agustus 2021, menyatakan bahwa teknik supervisi akademik dilaksanakan melalui kunjungan kelas secara virtual tetapi guru yang akan disupervisi berada di satu kelas dengan supervisor yaitu kepala sekolah dan didampingi oleh wakil kepala sekolah urusan kurikulum. Kunjungan kelas ini sebagai salah satu teknik untuk mengamati proses pembelajaran secara langsung terutama dalam kesiapan guru mata pelajaran mengajar yang dibuktikan dengan administrasi pembelajaran berupa jadwal mengajar, silabus, kalender pendidikan, Program Tahunan, Program Semester, RPP (Rencana Pelaksanaan
Pembelajaran), penggunaan media yang digunakan dalam pembelajaran, Kisikisi/Instrumen Penilaian, Program Remidial, Program Pengayaan, Buku Nilai, Buku Guru. Dengan kualifikasi penilaian persentase (\%) Jawaban "Ya" = Jumlah skor diperoleh x 100/12.

\section{b. SMA PGII 2}

Berdasarkan hasil observasi, wawancara dan studi dokuemntasi dengan Kepala SMA PGII 2 pada hari Rabu, tanggal 19 Agustus 2021, menyatakan bahwa teknik supervisi akademik dilaksanakan melalui kunjungan kelas secara virtual. Pelaksanaan supervisi tidak hanya pada supervisi akademik saja tetapi juga supervisi yang berhubungan dengan keprofesionalan guru yaitu supervisi kepribadian dan supervisi sosial. Supervisi keprofesionalan ini bertujuan untuk mengetahui sejauh mana kualitas guru yang ada. Dan supervisi ini termasuk supervisi internal, di SMA PGII 2 dilaksanakan juga supervisi eksternal yang dilaksanakan oleh yayasan dari bagian kependidikan, dikarenakan yayasan perlu juga untuk melakukan evaluasi terhadap guru-guru yang mengajar. Hasil evaluasi tersebut sebagai rujukan untuk dibawa pada rapat kerja. Dan untuk supervisi eksternal juga dilakukan oleh pengawas Pembina. Untuk supervisi eksternal ini hanya menilai standar profesional dan standar pedagogik dari guru-guru. Untuk standar sosial dan standar kepribadian tetap dilakukan supervisi oleh kepala sekolah.

3) Kegiatan Kepala sekolah dalam mengevaluasi hasil supervisi akademik dalam meningkatkan kompetensi profesional guru.

a. SMA Kartika XIX-I

Hasil observasi, wawancara dan studi dokumentasi dengan kepala SMA Kartika XIX-1 pada hari Senin, tanggal 25 Agustus 2021, menyatakan bahwa kegiatan kepala sekolah dalam menindaklanjuti hasil supervisi yaitu dengan cara melaksanakan kunjungan kelas secara virtual atau observasi kelas, kemudian dideskripsikan dalam isian format rekaman hasil supervisi 
akademik setiap guru yang dideskripsikan dalam program tindak lanjut berupa perbaikan, pembinaan dan penguatan. Sebagai bukti pelaksanaan supervisi akademik, kepala sekolah mengisi format rekaman hasil supervisi yang terdiri dari temuan masalah, nilai tambah, saran, tindak lanjut dan rekomendasi. Dari hasil pelaksanaan supervisi akademik ini adanya faktor penghambat dalam pelaksanaan supervisi akademik, di antaranya adalah (1) Seringkali jadwal yang sudah dibuat tidak bisa terlaksana dikarenakan kepala sekolah yang tiba tiba memiliki agenda atau kegiatan yang lain. Tetapi jika kepala sekolah tiba-tiba berhalangan untuk hadir mensupervisi kegiatan akademis maka bisa di tangani oleh wakil kepala sekolah urusan kurikulum ataupun guru inti yang sudah betul betul baik dalam pelaksanaan proses pembelajarannya; (2) Masih ada guru yang belum siap pada saat jadwal supervisi yang sudah ditentukan. (3) guru-guru yang terkadang masih kembali lagi menjadi tidak mengikuti prosedur yang benar jika tidak di supervisi oleh kepala sekolah. Adapun faktor pendukung dalam pelaksanaan supervisi akademik ini adalah (1) memiliki pengawas Pembina yang pro aktif dan dikarenakan supervisi akademik sudah menjadi program tetap yang harus dilaksanakan setiap tahun, dan pengawas pembina aktif sekali dalam melakukan pengawasan terhadap sekolah dan guru-guru, bahkan pada saat pelaksanaan supervisi akademik ini, pengawas Pembina ikut andil dalam mensupervisi guru-guru mata pelajaran secara langsung; (2) sarana dan prasarana yang sudah sangat cukup memadai untuk kegiatan supervisi akademik.

\section{b. SMA PGII 2}

Hasil evaluasi dari pelaskanaan supervisi akademik adanya faktor pendukung dalam pelaksanaan supervisi akademik adalah sarana dan prasarana yang sangat memadai dan faktor penghambat dalam pelaksanaan supervisi akademik ini adalah: seringkali jadwal yang sudah dibuat tidak bisa terlaksana dikarenakan kepala sekolah yang tiba tiba memiliki agenda atau kegiatan yang lain. Tetapi jika kepala sekolah tiba-tiba berhalangan untuk hadir mensupervisi kegiatan akademis maka bisa di tangani oleh wakil kepala sekolah urusan kurikulum ataupun guru inti yang sudah betul betul baik dalam pelaksanaan proses pembelajarannya, Pengaruh dari pelaksanaan supervisi akademik ini sangat baik sekali, jika guru-guru kreatif dalam menciptakan pembelajaran yang menyenangkan maka hal ini dapat meningkatkan kompetensi profesional guru. Dengan adanya supervisi akademik yang tidak monoton hanya melihat dari administrasi saja dapat meningkatkan kualitas dan mutu guru-guru disekolah.

\section{B. Pembahasan}

1) Kegiatan Kepala Sekolah dalam merencanakan supervisi akademik Data yang diperoleh dari dua kepala sekolah yang diteliti telah melaksanakan supervisi akademik melalui tahapan awal yaitu tahapan perencanaan. Kepala sekolah menyusun perencanaan yang matang. Pertama, menetapkan tujuan dan sasaran supervisi, yaitu melaksanakan perencanaan pada persiapan proses pembelajaran yang sesuai dengan visi dan misi serta tujuan sekolah masing-masing. Dari data dilapangan hasil perencanaan supervisi akademik diharapkan guru mampu melaksanakan proses pembelajaran dengan baik dan menyenangkan. Dari data pedoman supervisi akademik, kedua sekolah tersebut, menguraikan beberapa komponen yang berkaitan dengan kompetensi profesional yang disiapkan oleh kepala sekolah berkenaan dengan penilaian kemampuan guru dalam menyusun pelaksanaan pembelajaran yang meliputi: (1) merencanakan pengorganisasian bahan pembelajaran: menggunakan bahan pembelajaran sesuai dengan kurikulum sekolah, menentukan alokasi waktu, menyusun bahan pembelajaran/ materi dengan berbagai jenjang kemampuan; (2) merencanakan pengelolaan kegiatan pembelajaran: menentukan penggunaan alat dan media pembelajaran yang kreatif dan menarik, menentukan kompetensi dasar, menentukan tujuan pembelajaran, menentukan kegiatan 
pembelajaran yang terdari: kegiatan awal, kegiatan inti, dan kegiatan penutup (3) merencanakan penglolaan kelas secara virtual agar peserta didik bisa berpartisipasi dalam pembelajaran dan menciptakan pembelajaran yang menyena-ngkan; (4) menentukan penilaiam peserta didik: menentukan bentuk dan jenis penilaian, membuat alat penilaian, membuat kunci jawaban, dan membuat skor penilaian. Perencanaan yang matang telah dilakukan oleh kepala sekolah untuk melaksanakan supervisi akademik

2) Kegiatan Kepala Sekolah dalam melaksanakan supervisi akademik

Implementasi supervisi akademik untuk meningkatkan kompetensi profesional guru, menurut kedua kepala sekolah memiliki aspek-aspek yang harus dipersiapkan, agar memiliki landasan hukum supervisi, memiliki tujuan dan tepat sasaran, memilki jadwal supervisi, instrumen supervisi akdemik. Kepala sekolah mempersiapkan format penilaian yang harus dilengkapi sehingga guru lebih siap ketika akan disupervisi. Tentu saja setiap kepala sekolah memilki jadwal supervisi yang telah disusun. Kedua kepala sekolah menyampaikan jadwal melalui rapat dinas awal tahun pelajaran dan disampaikan juga melalui whatssapp grup sekolah. Kepala sekolah melaksanakan supervisi akademik berada didalam kelas dengan didampingi oleh wakil kepala sekolah urusan kurikulum, meskipun supervisi akademik dilaksanakan secara secara virtual, dengan demikian kepala sekolah dapat melihat penampilan guru dan penguasaan peserta didik. Sementara satu kepala sekolah yang lain melaksanakan supervisi akademik tanpa di dampingi oleh wakil kepala sekolah, dan pelaksanaan supervisi akademik ini dengan adanya kunjungan kekelas meskipun secara virtual. Kedua kepala sekolah mengisi format instrumen yang harus diberikan penilaian terhadap guru yang sedang disupervisi, kemudian memeriksa RPP dan menilai cara guru dalam mengevaluasi pembelajaran dan cara menutup pembelajaran dengan tepat. Setelah melakukan supervisi akdemik terhadap guru, Kedua kepala sekolah melakukan dialog atau melakukan diskusi kecil untuk mengevaluasi hasil dari supervisi tersebut.

3) Kegiatan Kepala Sekolah dalam mengevaluasi supervisi akademik Penelitian mengenai hasil dari evaluasi supervisi akademik terdapat faktor pendukung dan penghambat dalam meningkatkan kompetensi profesional guru di kedua sekolah pada dasarnya hampir sama, sebagai faktor pendukung, pertama kompetensi kepala sekolah yang didukung dengan guru keulifikasi pendidikan sarjana dan linier dibidangnya, berkpribadian luhur, dan diteladani guru, memiliki kemampuan manajerial, wawasan kepemimpinan yang luas, mampu melakukan supervisi dengan baik termasuk supervisi akademik, memiliki penglaman kerja yang cukup, memiliki jiwa wirausaha. Memiliki kemampuan teknologi, kemampuan berkomunikasi dengan baik, ketiga dukungna peserta didik, orang tua dan masayarakat. Keempat keuangan/ dana, kelima lingkungan sekolah yang kondusif, keenam sarana dan prasarana yaag memadai. Adapun yang menjadi faktor penghambat pertam, kegiatan kepala sekolah yang padat, kesiapan guru terkait dengan faktor usia, keinginan untuk maju, dan kemmampuan berkomunikasi. Namun sebagai kepala sekolah harus mampu memanfaatkan faktor pendukung dan menyikapi faktor penghambat. Supervisi yang dilakukan oleh kedua kepala sekolah merupakan supervisi akademik. Hal tersebut merupakan sebuah upaya kepala sekolah dalam meningkatkan kompetensi profesional guru. Dengan adanya supervisi akademik ini sangat baik sekali bagi guru, peserta didik dan sekolah dan ini merupakan bantuan secara profesional kepada guru melalui perencanaan, pelaksanaan dan tindak lanjut supervisi akademik. Hal ini dilakukan untuk meningkatkan kinerja guru agar lebih profesional yang pada akhirnya bermuara kepada tercapainya tujuan pendidikan nasioanal yang kita harapkan yakni berkembangnya potensi peserta didik agar menjadi manusia yang beriman dan bertakwa kepada Tuhan Yang Maha Esa, berakhlak mulia, sehat, berilmu, cakap, kreatif, amdniri dan menjadi warga Negara yang demokratis serta bertanggung jawab. 


\section{SIMPULAN DAN SARAN}

\section{A. Simpulan}

Secara umum hasil dari penelitian ini dapat disimpulkan bahwa supervisi akademik yang dilakukan oleh kepala sekolah merupakan bantuan profesional kepada guru melalui siklus perencanaan yang sitematis, pelaksanaan observasi supervisi yang cermat, tindak lanjut yang objektif. Dengan cara tersebut guru dapat menggunakan balikan untuk memperhatikan kinerja dan profesionalnya, jadi tujuan supervisi akademik adalah untuk meingkatkan kemampuan profesional guru dan meningkatkan kualitas pembelajaran melalui proses pembelajaran yang efektif. Adapun yang menjadi faktor pendukung dan penghambat dalam meningkatkan kompetensi profesional guru mata pelajaran adalah hal yang berkenaan dengan sumber daya manusia (kepala sekolah, guru, peserta didik, pengawas sekolah, orangtua/ masyarakat), keuangan, sarana prasarana, dan iklim kerja.

Berdasarkan serangkaian hasil penelitian dan analisis baik yang berasal dari studi dokumentasi, observasi dan hasil wawancara dengan para narasumber di lapangan perlu kiranya penulis memberikan beberapa rekomendasi kepada: Pengawas pendidikan, disarankan untuk terus memberikan motivasi kepada kepala sekolah untuk meningkatkan kinerja sebagai supervisor. Pengawas hendaknya selalu memantau kegiatan kepala sekolah dan guru mata pelajaran demi terciptanya iklim sekolah yang kondusif dan berkualitas. Kepala sekolah, disarankan untuk terus menerus memotivasi guru-guru mata pelajaran untuk meningkatkan profesional terkait dengan kompetensi yang harus dimilki demi tercapainya tujuan pembelajaran yang telah dirumuskan dan dapat meningkatkan mutu lulusan. Guru, disarankan utnuk terus meningkatkan kompetensi profesional dan kinerja agar menjadi guru profesional dan melaksanakan tugas dengan baik. Melalui pelaksanaan supervisi akademik yang dilakukan oleh kepala sekolah dapat dijadikan motivasi guru dalam meningkatkan kinerja dan menciptakan lulusan yang berkualitas. Peneliti selanjutnya.

\section{B. Saran}

Adapun saran yang dapat disampaikan peneliti adalah agar peneliti selanjutnya diharapkan dapat menambah kekurangankekurangan pada penelitian ini.

\section{DAFTAR RUJUKAN}

Al-Quran Terjemahan. (2015). Departemen Agama RI. Bandung: CV Darus Sunnah.

Departemen Agama RI, Al-Qur'an dan Terjemahannya, (Depok: SABIK,2015), 53.

Govindarajan Vijay \& Anthony, (1998). Management Control System. Mc Cllelan Grawhill.

Hermino Agustinus, (2014). Kepemimpinan Pendidikan. Yogyakarta: Pustaka Pelajar.

Kempa Rudolf, (2009). Perilaku Kepemimpinan, Keterampilan Manajerial, Manajemen Konflik, Daya Tahan Stress, dan Kinerja Guru Jurnal Ilmu Pendidikan. Jakarta: LPTK dan ISPL.

Lantip Diat Prasojo, dan Sudiyono, (2011). Supervisi Pendidikan. yogyakarta: Gava Media.

Mulyasa, (2011). Manajemen Berbasis Sekolah, Konsep, Strategi dan Implementasi. Bandung: PT Remaja Rosda Karya.

Prasojo, Lantip Diat dan Sudiyono, (2011). Supervisi Pendidikan. Yogyakarta: Gava Media

Sutarsih Cicih, (2011), Perencanaan Supervisi Akademik. Jakarta: Sarana Panca Karya Nusa

Widjaja Amin, (1993). Manajemen Suatu Pengantar. Jakarta: Renika Cipta

Undang-Undang Nomor 20 Tahun 2003 tentang Sistem Pendidikan Nasional

Undang-Undang Nomor 14 Tahun 2005 tentang Guru dan Dosen.

Peraturan Pemerintah Nomor 13 Tahun 2007 tentang Standar Kepala Sekolah.

Peraturan Pemerintah Nomor 14 Tahun 2005 tentang Guru dan Dosen. 